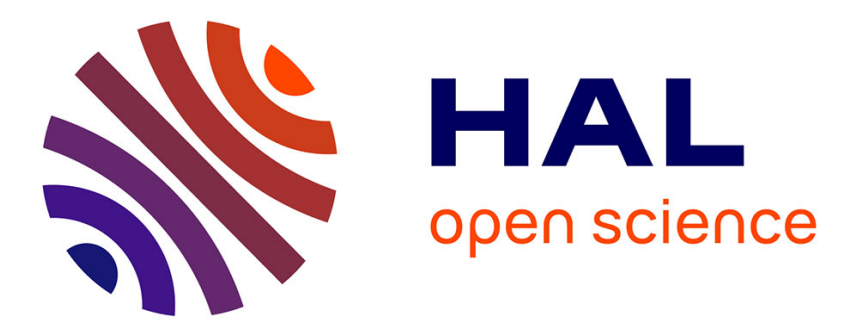

\title{
Reversible $\mathrm{P}-\mathrm{C}$ bond formation for saturated $\alpha$-aminophosphine ligands in solution: stabilization by coordination to $\mathrm{Cu}(\mathrm{I})$
}

Jacques Andrieu, Jochen Dietz, Rinaldo Poli, Philippe Richard

\section{- To cite this version:}

Jacques Andrieu, Jochen Dietz, Rinaldo Poli, Philippe Richard. Reversible P-C bond formation for saturated $\alpha$-aminophosphine ligands in solution: stabilization by coordination to $\mathrm{Cu}(\mathrm{I})$. New Journal of Chemistry, 1999, 23 (6), pp.581-583. 10.1039/A902783A . hal-03299574

\section{HAL Id: hal-03299574 \\ https://hal.science/hal-03299574}

Submitted on 28 Jul 2021

HAL is a multi-disciplinary open access archive for the deposit and dissemination of scientific research documents, whether they are published or not. The documents may come from teaching and research institutions in France or abroad, or from public or private research centers.
L'archive ouverte pluridisciplinaire HAL, est destinée au dépôt et à la diffusion de documents scientifiques de niveau recherche, publiés ou non, émanant des établissements d'enseignement et de recherche français ou étrangers, des laboratoires publics ou privés. 
Reversible P-C bond formation for saturated $\alpha$-aminophosphine ligands in solution: stabilisation by coordination to $\mathrm{Cu}(\mathrm{I})$

\section{Jacques Andrieu*, Jochen Dietz, Rinaldo Poli*, and Philippe Richard}

Laboratoire de Synthèse et d'Electrosynthèse Organométalliques, Faculté des Sciences "Gabriel", Université de Bourgogne, 6 Boulevard Gabriel, 21100 Dijon, France

Correspondence to: Prof. Rinaldo Poli and Dr. Jacques Andrieu

Laboratoire de Synthèse et d'Electrosynthèse Organométalliques

Faculté des Sciences "Gabriel"

6, Boulevard Gabriel

21100 Dijon (France)

tel: $+33-03.80 .39 .68 .81$

fax: $+33-03.80 .39 .60 .98$

E-MAIL: Rinaldo.Poli@u-bourgogne.fr 
Summary. The saturated $\alpha$-aminophosphine ligands containing a secondary amine function $P h_{2} P C H\left(R\right.$ ')NHR" establish a solution equilibrium with $P h_{2} P H$ and $R$ ' $C H=N R$ ” and are stabilized by electron-withdrawing substituents $R$ ' and $R$ " and by coordination of the phosphorus donor to $C u(I)$.

Since the discovery that bifunctional P,N ligands increase considerably the activity and/or the selectivity of palladium, ruthenium or rhodium catalysts, ${ }^{1-4}$ the preparation of this type of ligands has been the subject of extensive investigations. Amongst these ligands, $\alpha$-aminophosphines crucially control the activity and selectivity of alkyne methoxycarbonylation catalysts. ${ }^{1}$ Unsaturated ligands of this type (having an $\mathrm{sp}^{2}$-hybridized $\mathrm{N}$ donor) are exemplified by 2-PyPPh 2 $\left(\mathrm{Py}=\mathrm{C}_{5} \mathrm{H}_{4} \mathrm{~N}\right)$. Saturated versions of this class, i.e. $\mathrm{Ph}_{2} \mathrm{PCH}(\mathrm{R}) \mathrm{NR}^{\prime} \mathrm{R}$ " have received little attention. While the Mannich reaction between $\mathrm{Et}_{2} \mathrm{PH}, \mathrm{CH}_{2} \mathrm{O}$ and the $\mathrm{Me}_{2} \mathrm{NH}$ compounds leads to the stable (both in the solid state and in solution) $\mathrm{Ph}_{2} \mathrm{PCH}_{2} \mathrm{~N}\left(\mathrm{CH}_{3}\right)_{2}$ ligand having a tertiary amine function, ${ }^{5}$ aminophosphines prepared by addition of $\mathrm{Et}_{2} \mathrm{PH}$ to $\mathrm{CH}_{2}=\mathrm{N}^{\mathrm{t}} \mathrm{Bu}^{5}$ or $\mathrm{Ph}_{2} \mathrm{PH}$ to $\mathrm{PhCH}=\mathrm{NPh}^{6}$ without solvent have only been described in the solid state. The subsequent reaction with iodomethane leads to an unexpected P-C bond cleavage. ${ }^{6}$ Anionic $\alpha-\mathrm{P}, \mathrm{N}$ ligands prepared by nucleophilic addition of $\mathrm{Ph}_{2} \mathrm{P}^{-} \mathrm{Li}^{+}$to $\mathrm{PhCH}=\mathrm{NPh}$ or $\mathrm{RLi}$ to 2-PyPPh have also showed instability in solution. ${ }^{7,8}$ We now wish to present NMR and synthetic studies that enable us to rationalise the solution instability of $\alpha-\mathrm{P}, \mathrm{N}$ ligands with secondary amine functions and to understand the electronic factors that favor their stabilisation. 
The reaction of $\mathrm{Ph}_{2} \mathrm{P}^{-} \mathrm{Li}^{+}$with one equivalent of $\mathrm{N}$-benzylideneaniline, followed by quenching with water and extraction in toluene affords the desired product $\mathbf{2 a}$, see scheme I.

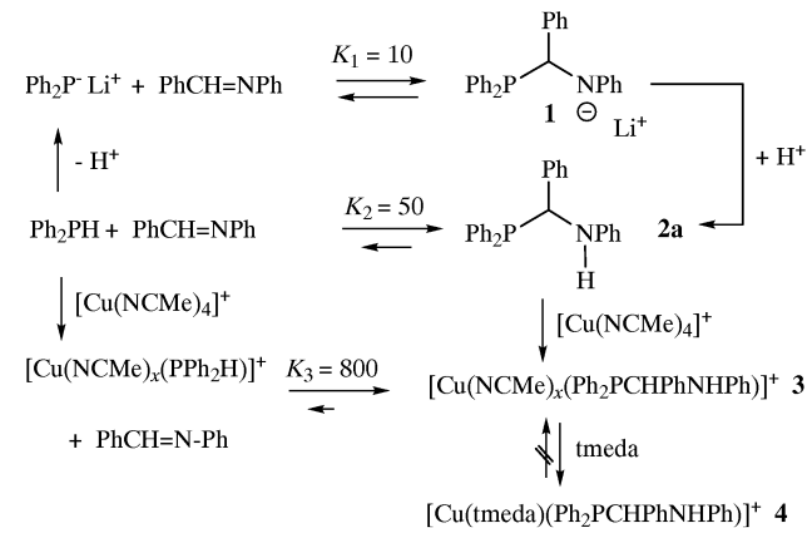

Scheme 1

The ${ }^{31} \mathrm{P}$ and ${ }^{1} \mathrm{H}$ NMR spectroscopic properties confirm the nature of the product. However, the NMR spectra of the redissolved crystallised product show the presence of the diphenylphosphine and imine starting materials in amounts that increase with time, indicating a reversible $\mathrm{P}-\mathrm{C}$ bond cleavage. NMR monitoring of this process in $\mathrm{CDCl}_{3}$ (integration of the ${ }^{1} \mathrm{H}$ NMR imine $\mathrm{CH}=\mathrm{N}$ and product $\mathrm{P}-\mathrm{CH}-\mathrm{N}$ signals) reveals the establishment of a stable equilibrium position ( $\mathrm{t}_{1 / 2}=10 \mathrm{~min} ; \mathrm{K}_{2}=50 \mathrm{M}^{-1}$ after $>2$ days $)$, which was independently confirmed by NMR monitoring of the reaction between $\mathrm{Ph}_{2} \mathrm{PH}$ and $\mathrm{PhCH}=\mathrm{NPh}$. A closer examination shows that an analogous equilibrium is also established for the anionic species, although this is shifted to a weaker extent toward the PCN product 1 relative to the neutral system $\left(\mathrm{K}_{1}=10 \mathrm{M}^{-1}\right.$ by ${ }^{31} \mathrm{P}$ NMR integration in $\mathrm{THF} / \mathrm{C}_{6} \mathrm{D}_{6}$ ). Thus, our NMR experiments show that the instability of the $\alpha-\mathrm{P}, \mathrm{N}$ 
ligand and of its related anionic form in solution is due to a reversible $\mathrm{P}-\mathrm{C}$ bond formation, with proton migration for the neutral species.

The generalisation to a wider group of imines establishes the substituent effect on the equilibrium position (see Scheme II). In particular, the presence of an electron-withdrawing group has a beneficial effect on the ligand formation when this is located either on the nitrogen atom $(\mathbf{d}>\mathbf{a}>\mathbf{b}>\mathbf{c})$ or on the carbon atom $(\mathbf{e}>\mathbf{d})$. This study shows that the careful choice of substituents may allow the synthesis of stable (in solution) $\alpha-\mathrm{P}, \mathrm{N}$ saturated ligands.

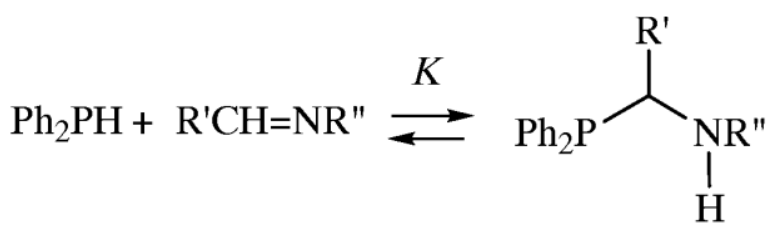

2a-e

\begin{tabular}{l|l|l|l} 
& $\mathrm{R}^{\prime}$ & $\mathrm{R}^{\prime \prime}$ & $K$ \\
\hline a & $\mathrm{Ph}$ & $\mathrm{Ph}$ & 50 \\
b & $\mathrm{Ph}$ & $\mathrm{CHMePh}$ & 10 \\
c & $\mathrm{Ph}$ & $\mathrm{CH}_{3}$ & 0.2 \\
d & $\mathrm{Ph}$ & $p-\mathrm{NO}_{2} \mathrm{C}_{6} \mathrm{H}_{4}$ & $>1000$ \\
e & $p-\mathrm{NO}_{2} \mathrm{C}_{6} \mathrm{H}_{4}$ & $\mathrm{CHMePh}$ & 390
\end{tabular}

Scheme 2

As we are interested in the exploration of the coordinating properties of these P,N ligands, we wished to examine whether coordination to a suitable metal could also affect the stability of the P-C bond. The above mentioned 2-PyPPh2 ligand is known to act as an assembling ligand (adopting a $\mu-\eta^{2}$ coordination mode) in dinuclear copper(I) and in numerous other polynuclear 
complexes. $^{4,9}$ Addition of one equivalent of $\left[\mathrm{Cu}(\mathrm{NCMe})_{4}\right]\left(\mathrm{BF}_{4}\right)^{10}$ to the equilibrium mixture containing 2, $\mathrm{Ph}_{2} \mathrm{PH}$ and $\mathrm{PhCH}=\mathrm{NPh}$ in $\mathrm{CDCl}_{3}$ produces a solution with a major ${ }^{31} \mathrm{P}$ NMR resonance at $\delta=-3.90$ and a minor one at $\delta=-35.2$ corresponding to the copper complexes $\left[\mathrm{Cu}(\mathrm{NCMe})_{x}\left(\mathrm{Ph}_{2} \mathrm{PCHPhNHPh}\right)\right]\left(\mathrm{BF}_{4}\right) 3$, and $\left[\mathrm{Cu}(\mathrm{NCMe})_{x}\left(\mathrm{PPh}_{2} \mathrm{H}\right)\right]\left(\mathrm{BF}_{4}\right)$, respectively $(\mathrm{Scheme}$ I). Only traces of coordinated $\mathrm{Ph}_{2} \mathrm{PH}$ and free $\mathrm{PhCH}=\mathrm{NPh}$ have been detected in the ${ }^{1} \mathrm{H}$ NMR spectrum $\left(\mathrm{K}_{3}=800 \mathrm{M}^{-1}\right)$, indicating an almost quantitative shift of the equilibrium. This result shows that removal of electron density from the phosphine end of the molecule also stabilizes the P-C bond.

Compound $\mathbf{3}$ is highly unstable, even in neat $\mathrm{MeCN}$, leading to the slow precipitation of metallic copper. Addition of $\mathrm{Me}_{2} \mathrm{NCH}_{2} \mathrm{CH}_{2} \mathrm{NMe}_{2}$ (tmeda), on the other hand, yields stable $\left[\mathrm{Cu}(\right.$ tmeda $\left.)\left(\mathrm{Ph}_{2} \mathrm{PCHPhNHPh}\right)\right]\left(\mathrm{BF}_{4}\right) 4$, with NMR properties quite similar to those of $\mathbf{3}$. White single crystals of 4 were obtained from $\mathrm{CHCl}_{3}$. The geometry of the cation, shown in Figure 1, reveals a rare example of three-coordination for a $\mathrm{Cu}(\mathrm{I})$ complex. ${ }^{11,12}$ The $\alpha-\mathrm{P}, \mathrm{N}$ ligand is only $\mathrm{P}$-coordinated and the amino function remains dangling, whereas the analogous 2-PyPPh 2 ligand always adopts a $\mu-\mathrm{P}, \mathrm{N}$ coordination mode in dinuclear copper complexes. ${ }^{9,11}$ Note that a fluxional behaviour interconverting $\mathrm{P}$ - and $\mathrm{N}$-coordinated ligands in solution is inconsistent with the observed variation of the ${ }^{31} \mathrm{P}$ chemical shift from the free to the coordinated ligand, which is similar to that observed for the 2-PyPPh2 system. 


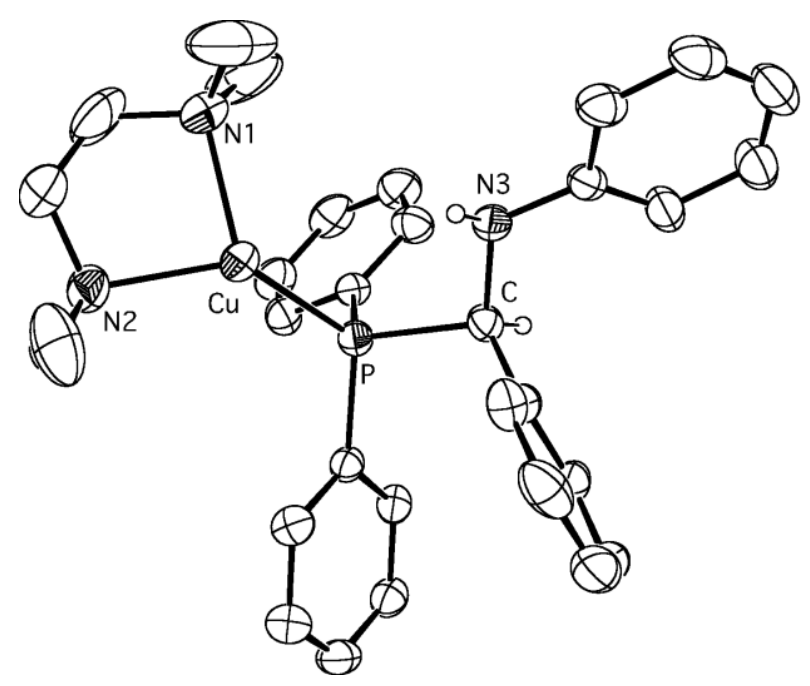

Fig. 1. An ORTEP view of the cation of compound 4. Selected bond distances $(\AA)$ and angles $\left(^{\circ}\right)$ : Cu-N1, 2.073(6); Cu-N2, 2.104(6); Cu-P, 2.153(2); P-C, 1.878(6); C-N3, 1.466(8); N1-CuN2, 87.7(2); N1-Cu-P, 133.9(2); N2-Cu-P, 126.8(2); N3-C-P, 104.8(4).

In conclusion, we have shown that the instability of $\alpha-\mathrm{P}, \mathrm{N}$ ligands with a secondary amine function and their corresponding anions in solution is due to reversible P-C bond formation, which can be reduced or suppressed by a decrease of electron density. This can be accomplished by either electron withdrawing substituents on the nitrogen or carbon atoms, or by coordination of the phosphorus donor. These results allow an easy and rapid access to new complexes with saturated $\alpha$-aminophosphine ligands. Further studies are in progress in order to control the chirality of the central carbon atom $\left(\mathrm{P}-\mathrm{C}^{*}-\mathrm{N}\right)$ and to explore the coordination properties of $\alpha-\mathrm{P}, \mathrm{N}$ ligands toward early and late transition metals.

\section{Acknowledgments}


We acknowledge the Conseil Régional de Bourgogne and the CNRS for support of this work and the European Commission for an Eramus exchange undergraduate student program concerning Jochen Dietz from the University of Kaiserslautern, Germany.

\section{Experimental}

All manipulations were carried out under an atmosphere of purified nitrogen using standard Schlenk techniques. All solvents were dried and deoxygenated prior to use. All chemical shifts are given in ppm.

Reversible formation of compounds 2a-e. To a solution of $\mathrm{PhCH}=\mathrm{NPh}(0.312 \mathrm{~g}, 1.72 \mathrm{mmol})$ in $\mathrm{CDCl}_{3}(10 \mathrm{ml})$ was added $\mathrm{Ph}_{2} \mathrm{PH}(0.300 \mathrm{ml}, 1.72 \mathrm{mmol})$. The mixture was stirred for $2 \mathrm{hrs}$, yielding an equilibrium of $\mathbf{2 a}$ with the starting materials. ${ }^{1} \mathrm{H}$ NMR $\left(\mathrm{CDCl}_{3}\right): \delta=7.97-6.68(\mathrm{~m}, 20 \mathrm{H}$ aromatics), $5.16\left(\mathrm{dd}, 1 \mathrm{H}, \mathrm{PCH},{ }^{2} J(\mathrm{P}, \mathrm{H})=3.2 \mathrm{~Hz},{ }^{3} J(\mathrm{H}, \mathrm{H})=6.5 \mathrm{~Hz}\right), 4.41\left(\mathrm{dd}, 1 \mathrm{H}, \mathrm{NCH},{ }^{3} J(\mathrm{P}, \mathrm{H})\right.$ $=3.8 \mathrm{~Hz},{ }^{3} \mathrm{~J}(\mathrm{H}, \mathrm{H})=6.5 \mathrm{~Hz}$, exchange readily with $\left.\mathrm{D}_{2} \mathrm{O}\right) .{ }^{31} \mathrm{P} \mathrm{NMR}\left(\mathrm{CDCl}_{3}\right): \delta=3.70 \mathrm{ppm}(\mathrm{s}) .{ }^{13} \mathrm{C}$ $\operatorname{NMR}\left(\mathrm{CDCl}_{3}\right): \delta=140.00-113.72(\mathrm{~m}, 24 \mathrm{C}$ aromatics $), 56.92\left(\mathrm{~d}, 1 \mathrm{C}, \mathrm{PCH},{ }^{1} J_{(\mathrm{PC})}=14.0 \mathrm{~Hz}\right)$.

By analogous reactions, equilibrium mixtures of compounds $2 \mathbf{b}$-e with the corresponding starting materials were obtained (equilibrium constants as indicated in Table II). ${ }^{1} \mathrm{H} \mathrm{NMR}\left(\mathrm{CDCl}_{3}\right)$. PCHN proton: 4.12 and $4.10\left(\mathbf{2 b}, \mathrm{d},{ }^{2} J_{\mathrm{PH}}=9.8 \mathrm{~Hz}\right.$, and ${ }^{2} J_{\mathrm{PH}}=5.6 \mathrm{~Hz}$ respectively $), 4.22(\mathbf{2 c}, \mathrm{d}$, $\left.{ }^{2} J_{\mathrm{PH}}=9 \mathrm{~Hz}\right), 5.20\left(\mathbf{2 d}, \mathrm{dd},{ }^{2} J_{\mathrm{PH}}=7.0 \mathrm{~Hz},{ }^{3} J_{\mathrm{HH}}=2.9 \mathrm{~Hz}\right), 4.63$ and $4.27\left(\mathbf{2 e}, \mathrm{d},{ }^{2} J_{\mathrm{PH}}=9.8 \mathrm{~Hz}\right.$ and ${ }^{2} J_{\mathrm{PH}}=5.6 \mathrm{~Hz}$ respectively); NH proton: $2.35(\mathbf{2 b}, \mathrm{s}, \mathrm{br}), 4.28\left(\mathbf{2 c}, \mathrm{d},{ }^{3} \mathrm{~J}_{\mathrm{PH}}=5.8 \mathrm{~Hz}\right), 5.05(\mathbf{2 d}, \mathrm{dd}$, $\left.{ }^{3} J_{\mathrm{PH}}=6.7 \mathrm{~Hz},{ }^{3} J_{\mathrm{HH}}=2.9 \mathrm{~Hz}\right), 2.03(\mathbf{2 e}, \mathrm{s}, \mathrm{br}) .{ }^{31} \mathrm{P} \mathrm{NMR}\left(\mathrm{CDCl}_{3}\right): 1.49$ and $0.89(\mathbf{2 b}), 1.20(\mathbf{2 c})$, $5.78(\mathbf{2 d}), 4.85$ and 4.61 (2e). Compounds $\mathbf{2 b}$ and $\mathbf{2 e}$ are present as both possible diastereoisomers. 
Preparation of compound 4. The equilibrium solution of ligand 2a obtained as described above was transferred to a Schlenk tube containing $\left[\mathrm{Cu}(\mathrm{NCMe})_{4}\right]\left(\mathrm{BF}_{4}\right)(0.540 \mathrm{~g}, 1.72 \mathrm{mmol})$ and the mixture was stirred for $1 \mathrm{hr} .{ }^{1} \mathrm{H}$ NMR $\left(\mathrm{CDCl}_{3}\right): \delta=7.46-6.46(\mathrm{~m}, 20 \mathrm{H}$ aromatics), $5.23(\mathrm{~s}, \mathrm{~b}, 1 \mathrm{H}$, $\mathrm{PCH}), 4.61(\mathrm{~s}, \mathrm{~b}, 1 \mathrm{H}, \mathrm{NCH}), 2.00\left(\mathrm{~s}, \mathrm{~b}, 12 \mathrm{H}, \mathrm{CH}_{3} \mathrm{CN}\right.$, free and coordinated were not separated). ${ }^{31} \mathrm{P} \mathrm{NMR}\left(\mathrm{CDCl}_{3}\right): \delta=-3.90(\mathrm{~s}) .{ }^{13} \mathrm{C} \mathrm{NMR}\left(\mathrm{CDCl}_{3}\right): \delta=145.57-113.57$ (m, 48C aromatics), 56.95 (s, b, 2C, PCH). In a control experiment, coordination of $\mathrm{PHPh}_{2}$ to $\mathrm{Cu}(\mathrm{MeCN}) 4^{+}$yields a ${ }^{31} \mathrm{P} \mathrm{NMR}$ resonance at $\delta=-34.7$. To this solution was added tmeda $(0.26 \mathrm{ml}, 1.72 \mathrm{mmol})$. The resulting solution was stirred for 2 hrs, filtered and concentrated to half volume. Complex 4 was isolated by precipitation with $\mathrm{Et}_{2} \mathrm{O}$ and washed twice with this solvent. Colorless crystals were obtained from $\mathrm{CHCl}_{3}(0.742 \mathrm{~g}, 68 \%) .{ }^{1} \mathrm{H} \mathrm{NMR}\left(\mathrm{CDCl}_{3}\right): \delta=7.58-6.60(\mathrm{~m}, 20 \mathrm{H}$ aromatics $), 5.36(\mathrm{~m}, 2 \mathrm{H}, \mathrm{PCH}+$ $\mathrm{NCH}), 2.61$ (s, b, 4H, $\mathrm{NCH}_{2}$ coordinated), 2.43 (s, b, 12H, $\mathrm{NCH}_{3}$ coordinated). ${ }^{31} \mathrm{P} \mathrm{NMR}\left(\mathrm{CDCl}_{3}\right)$ : $\delta=13.77(\mathrm{~s}) .{ }^{13} \mathrm{C} \mathrm{NMR}\left(\mathrm{CDCl}_{3}\right): \delta=134.32-114.27$ (m, 24C aromatics), 58.00 (s, b, 1C, PCH), 48.36 (s, b, 6C, $\mathrm{NCH}_{3}+\mathrm{NCH}_{2}$ from tmeda coordinated). Elemental analysis: Calcd for $\mathrm{C}_{32} \mathrm{H}_{38} \mathrm{~N}_{3} \mathrm{PF}_{4} \mathrm{Cu}: \mathrm{C}$ 60.55, H 6.04, N 6.62; Found: C 60.33, H 5.92, N 6.43.

X-ray structure analysis of compound 4. Crystal dimensions: $0.3 \times 0.3 \times 0.2$ (mounted in capillary). The data collection was carried out on a CAD4 Enraf-Nonius goniometer. The structure was solved by interpretation of the Patterson map and subsequent difference Fourier techniques. All nonhydrogen atoms were refined anisotropically. ${ }^{13}$ Crystal and refinement data: $\mathrm{C}_{32} \mathrm{H}_{38} \mathrm{~N}_{3} \mathrm{PF} 4 \mathrm{Cu}, M_{\mathrm{r}}$ =634.20, orthorhombic, space group Pna2 $1, a=19.528(1), b=16.812(1), c=9.719(1) \AA, Z=4$, $\mathrm{V}=3190.8(4) \AA^{3}, \rho$ calcd $=1.320 \mathrm{~g} \cdot \mathrm{cm}^{-3}$, MoK $\alpha$ radiation $(\lambda=0.71073 \AA), \mu($ MoK $\alpha)=0.782 \mathrm{~mm}^{-}$ ${ }^{1}, \mathrm{~F}(000)=1320,2369$ independent reflections measured up to $\sin (\theta) / \lambda=0.616$. Final residual 
indices: $R_{w}\left(F^{2}\right)=0.096$ for all data and $R(F)=0.035$ for 1867 reflections with $\mathrm{I}>2 \sigma(\mathrm{I})$, G.O.F. $=$ 1.072. Crystallographic data for the structure reported in this paper have been deposited with the Cambridge Crystallographic Data Center as supplementary publication no CCDC-105288.

\section{References}

1 E. Drent, P. Arnoldy and P. H. M. Budzelaar, J. Organomet. Chem. 1993, 455, 247-253.

2 H. Yang, M. Alvarez, N. Lugan, R. Mathieu, J. Chem. Soc. Chem. Comm. 1995, 1721-1722.

3 H. Brunner, A. F. M. Mokhlesur Rahman, Chem. Ber. 1984, 710-724.

4 G. R. Newkome, Chem. Rev. 1993, 93, 2067-2089.

5 K. Issleib, M. Lischewski, A. Zshunke, Z. Chem. 1974, 14, 243-244.

6 A. N. Pudovik, G. V. Romanov, V. M. Pozhidaev, Z. Obsc. Chim. 1978, 48, 1008-1013.

$7 \quad$ K. Kellner, A. Tzschach, Z. Chem. 1984, 24, 365-375.

8 P. H. M. Budzelaar, J. Org. Chem. 1998, 63, 1131-1137.

9 E. Lastra, M. P. Gamasa, J. Gimeno, M. Lanfranchi, A. Tiripicchio, J. Chem. Soc. Dalton Trans. 1989, 1499-1506.

10 G. J. Kubas, Inorg. Synth. 1979, 19, 90-91.

11 W. H. Chan, S. M. Peng, C. M. Che, J. Chem. Soc. Dalton Trans. 1998, 2867-2871.

12 J. Andrieu, P. Braunstein, A. Tiripicchio, F. Ugozzoli, Inorg. Chem. 1996, 35, 5975-5985.

13 G. M. Sheldrick, SHELXS and SHELXL97; University of Göttingen, Göttingen, Germany, 1997. 